\title{
Uudenlaisia erityisopettajia aikuisten oppimisen tueksi
}

\author{
TARJALADONLAHTI
}

Yliopistojen tutkinnonuudistuksen myötä alkoi Jyväskylän yliopiston erityispedagogiikan laitoksella uudenlainen aikuiserityiskasvatuksen koulutus. Koulutus valmistaa opettajia ja ohjaajia oppimisessaan erityistä tukea tarvitseville, perusopetusiän ohittaneille nuorille ja aikuisille.

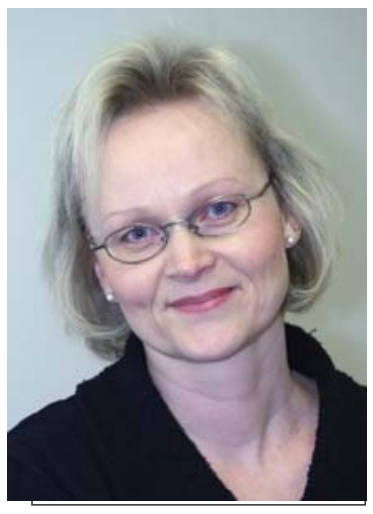

A jatus elinikäisestä oppimisesta on nykypäivää. Elinikäisen oppimisen tuomat haasteet ovat varsin moninaiset ja ne koskevat myös erilaisia oppija- tai opiskelijaryhmiä, joilla on oppimisvaikeuksia ja jotka tarvitsevat oppimisessaan tukea. Pysyäkseen mukana oman alansa kehityksessä tulee jokaisen opiskella jatkuvasti uusia asioita, jotka liittyvät sekä omaan alaan että erilaisiin tietoyhteiskunnan välineisiin ja menetelmiin. Moni rakentaa myös opintonsa polkua vähitellen ja tavoittelee opintojensa myötä uudenlaisia työtehtäviä.

Perusopetuksen oppioikeuksien ja/tai -velvollisuuksien toteuduttua sen luonnollisena seurauksena korostuu kysymys myös erityistä tukea tarvitsevien henkilöiden jatkokoulutuksesta ja työllistymisestä. Työelämän ja muodollisen koulutuksen lisäksi moni erityistä tukea tarvitseva henkilö, esimerkiksi kehitysvammaiseksi tai autistiseksi luokiteltu tai mielenterveyskuntoutuja tarvitsee tukea opetellessaan elämistä uudenlaisissa aikaisempaa avoimemmissa toiminta- ja asuinympäristöissä. Oikeus elinikäiseen oppimiseen koskee kaikkia.

\section{Uudenlaisen asiantuntemuksen} tarve on ilmeinen

Uuden aikuiserityiskasvatuksen koulutuksen taustalla on kentältä, erilaisista oppimisympäristöistä tullut selkeä viesti, että aikuisten oppimisvaikeuksien tunnistamisen - kuin myös monien oppimiseen liittyvien haasteiden - lisäännyttyä erilaisiin oppimisympäristöihin kaivattaisiin myös uudenlaista asiantuntijuutta ja uudenlaisia ohjaajia ja opettajia. Koulutuksella pyritään palvelemaan tätä tarvetta.

Koulutus on uuden tutkintorakenteen mukaisesti kaksiportainen. Opiskelijat valmistuvat ensin kasvatustieteen kandidaatiksi ja jatkavat suoraan maisterin tutkintoon. Koulutus sisältää sekä opettajan pedagogiset opinnot että erityisopetuksen tehtäviin ammatillisia valmiuksia antavat opinnot, mutta jättävät tilaa myös laajoille sivuaineopinnoille ja siten oman opettajuuden laajentamiselle.

Opintojen toteutuksessa ovat mukana Jyväskylän yliopiston kasvatustieteiden tiedekunnan eri laitokset. Kasvatustieteen laitoksen asiantuntijuutta hyödynnetään sekä yhteisissä kasvatustieteen perusopinnoissa että aikuiskouluttajille suunnatuissa pedagogisissa opinnoissa. Opettajankoulutuslaitoksen kanssa tehdään yhteistyötä joissakin opettajan pedagogisiin opintoihin kuuluvissa opintojaksoissa. Erityisopetukseen ammatillisia valmiuksia antavista opinnoista vastaa erityispedagogiikan laitos. 
Koulutuksen sisällölliset haasteet ovat moninaiset. Peruskoulutuksessa perehdytään laajaan kirjoon erilaisia oppimisvaikeuksia, oppimisen ongelmien taustalla oleviin syihin ja tekijöihin sekä ongelmien ilmenemismuotoihin. Aineopinnoissa keskitytään jo oppimisen ohjaamisen käytänteisiin ja aikuisille oppijoille soveltuviin oppimisen ohjaamis- ja opetusmenetelmiin. Aineopintojen aikana rakennetaan yleisluonteista erityiskasvatuksen ja -opetuksen osaamista eli keskitytään asioihin, jotka ovat kaikille erityisopettajille ja -kasvattajille tarpeellisia ja hyödyllisiä. Syventävissä maisterivaiheen opinnoissa opiskelijalla onkin jo mahdollisuus suuntautua selkeämmin omien mielenkiinnon kohteidensa mukaan ja erikoistua itseään kiinnostaviin kysymyksiin. Tätä omaa suuntautuneisuuttaan ja erikoisosaamistaan opiskelija voi myös vahvistaa valitsemalla itselleen mielekkäitä harjoittelupaikkoja sekä kohdentamalla opinnäytetöidensä aiheita tärkeiksi ja itselleen läheisiksi kokemiinsa aiheisiin.

\section{Pioneerityötä}

Koulutukseen valitut ensimmäiset 18 opiskelijaa aloittivat opintonsa 1.9.2005. Valtaosin opiskelijoilta tullut palaute syksyn opinnoista on ollut myönteistä. Opiskelijoiden kanssa käydyissä keskusteluissa (HOPS-keskustelut) ovat alkuun opiskelijoita luonnollisesti mietityttäneet $\mathrm{mm}$. kysymykset siitä, mikä minusta valmistumisen jälkeen tulee ja minkälaisiin työyhteisöihin ja työtehtäviin voisin koulutuksen jälkeen sijoittua. Näitä kysymyksiä pohtivat erityisesti nuoret opiskelijat. Työelämässä jo vankan jalansijan ja paljon kokemusta saaneet opiskelijat puolestaan ovat lähinnä tulleet hakemaan sisällöllistä osaamista ja muodollista kelpoisuutta nykyiseen opetus-, koulutus- tai kasvatustyöhönsä.

Luonnollisesti koulutus ja siitä valmistuvat opiskelijat hakevat alkuun paikkaansa, sillä uusi koulutus on monille työnantajillekin vielä tuntematon. Nähtäväksi jääkin miten uusi koulutus löytää paikkansa nykyisten, työelämässä jo muotonsa ja asemansa vakiinnuttaneiden koulutusten joukossa. Tähänastiset yhteydenotot ja viestit lupaavat hyvää. Toivottavasti yhä useampi erilaisissa koulutusorganisaatioissa tai erilaisissa toiminta- ja oppimisympäristöissä vaikuttava alansa ammattilainen herää pohtimaan, olisiko meidän työyhteisössä tarvetta tai tilaa aikuisen oppimisen ongelmiin ja haasteisiin perehtyneelle aikuiserityiskasvatuksen ja -opetuksen asiantuntijalle. Sitä kautta toivottavasti myös nykyistä useampi aikuinen henkilö saa uusia mahdollisuuksia ja tarvitsemaansa tukea henkilökohtaisella opiskelupolullaan.

\section{Lähteitä}

Eteläpelto, A. \& Tynjälä, P. (toim.) 1999. Oppiminen ja asiantuntijuus. Työelämän ja koulutuksen näkökulmia. WSOY.

Jakku-Sihvonen, R. (toim.) 2005. Uudenlaisia maistereita. Kasvatusalan koulutuksen kehittämislinjoja. PS-kustannus.

Kasvatustieteiden tiedekunnan opinto-opas 2005-2007. 2005 Jyväskylän yliopisto.

Ladonlahti, T. \& Pirttimaa, R. (toim.) 2003. Erityispedagogiikka ja aikuisuus. 3. painos. Palmenia. 